\title{
Girish Karnad's Tughlaq and Ali Ahmed Bakathir's Sir Al-Hakim bi-Amr Allah: A Study of the Inhuman Faces of Tyranny
}

\author{
Mashhoor Abdu Al-Moghales ${ }^{1,2}$ \\ ${ }^{1}$ Department of English, Faculty of Education, Taiz University, Taiz, Republic of Yemen \\ ${ }^{2}$ Department of English, Faculty of Science and Arts, KKU, Bisha, KSA \\ Correspondence: Mashhoor Abdu Al-Moghales, Department of English, Faculty of Science and Arts-Bisha \\ Campus, KKU, Bisha, KSA. E-mail: famousm2001@yahoo.com
}

\author{
Received: February 14, 2014 Accepted: March 30, 2014 Online Published: May 27, 2014 \\ doi:10.5539/ells.v4n2p30 URL: http://dx.doi.org/10.5539/ells.v4n2p30
}

\begin{abstract}
This paper discusses tyranny, the abuse of power and religion, and loss of human values during the reign of two well-known ancient Muslim rulers, namely, Al-Hakim bi Amr Allah (The Ruler by God's Command), the sixth Fatimid Khalif of Egypt (996-1021) and Mohammed bin Tughlaq (1325-1351 AD) who is known as an eccentric ruler of India. Girish Karnad's Tughlaq (India) and Ali Ahmed Bakathir's Sir Al-Hakim bi-Amr Allah (Egypt) deal with the unfair practices of those two similar rulers over their people and the struggle of the people against them. They played dirty tricks of politics and religion during their reign. The paper also presents the crisis of values of those rulers who appear to be like the wild beasts killing innocent people to protect their crowns. Though, these two rulers belonged to the Islamic culture, which calls for justice, equality and peace; they wrecked havoc and posed to be god-like. They had established rules, contrary to the Quran and the teachings of Islam, and punished people for their disobedience.
\end{abstract}

Keywords: inhuman faces of tyranny, Abuse of Power, Girish Karnad, Ali Ahmed Bakathir, Tughlaq, Sir Al-Hakim bi-Amr Allah

\section{Introduction}

Plato and Aristotle define a tyrant as, "one who rules without law, looks to his own advantage rather than that of his subjects, and uses extreme and cruel tactics - against his own people as well as others" (Glad, 2002). Tyranny, abuse of power and suppression during the reign of many Muslim rulers is a recurrent issue throughout history in many societies and countries. Rulers had been unjust and they had mistreated their people and practised dirty games to control them to continue in power for the whole of their life. Some Muslim rulers have been criticised by Muslim and non-Muslim writers for their abuse of power and their tyranny. In the history of the Muslim rulers, two well-known rulers-Al-Hakim bi Amr Allah (The Ruler by God's Command) and Mohammed bin Tughlaq are known as dictators and mad rulers. Their abuse of power and tyranny have been manifested through the plays I have analysed. The Muslim rulers, in those two plays, exercise their power and authority on their people and their close associates and assassinate those who threaten their 'peace of mind' and those too who might be a danger for them in future.

The two writers belong to different cultures and religions, yet they share the same concern. Ali Ahmed Bakathir (1910-69), had predicted the political breakdown in the Arab world through many of his plays, considered to be a direct criticism on the Arab Muslim leaders. Bakathir's Sir Al-Hakim bi-Amr Allah (1947), translated as The Secret of the Ruler by God's Command, criticises a Muslim ruler named Abu Ali Mansur, known as Al-Hakim bi-Amr Allah, whose tyranny and dictatorship exceed all the limits. He is known as a mad ruler for his esoteric opinions and beliefs. He interprets the teachings of Islam to suit his desires and proposes himself to be a deity.

Girish Karnad (b. 1938), an Indian writer, criticises an Indian Muslim ruler who wrecks havoc in India during his rule as dramatised in Tughlaq (1964). In this play, Karnad satirises the socio-political situation of his country and focuses on a cynical Muslim ruler, Mohammed bin Tughlaq (1325-1351 AD) known as the mad Tughlaq, who pretends to be just and kind to his people but kills them in cold blood to solve a specific problem for which there were many solutions. His era ended in confusion and chaos in all fronts of life due to his cynical whims.

These two rulers in those two plays tend to lose their balance and integrity because of their lust for power. Both 
are mad because power had adversely affected them, which in turn, affected the stability of the individual and the nation as well. Manser's (2007) observation is relevant in this regard: "Power has an adverse effect on the integrity of those in authority and the more power they have, the worse they become" (Manser, p. 225). The analysis of the plays I have taken shows how power had negatively affected the two rulers, leading to a crisis of human values, tyranny, abuse of power and religion.

\section{Tyranny and Abuse of Power}

Tyranny of the ruler over all is exposed in the beginning of Tuqhlaq. The voices of the people reflect their stand towards the practices of the Sultan. Unlike the young man, the old man is fed up with the miserable situation of his country which has been devastated by the Sultan. The old man feels that the Sultan is a replica of the former ones. The writer introduces the young man and the old man to prepare his audience for the fact that every ruler is liked and disliked but it is the majority who determine, whether he is right or wrong. The majority as presented in the play are against the Sultan and only few people around him think that he is right. Those few people are fully responsible for the whims and follies of the Sultan. The young man's statement that the Sultan "isn't afraid to be human" is shallow. The Sultan's appearance in public and his speech to his people about his faults and shortcomings are a manipulation and a trick to win more supporters for his grand folly-moving the capital to Daulatabad.

The Sultan's soft verbal discourse and eloquence enclose his dictatorship and subjugation to show people that he acts only to fulfil their wishes. The Sultan polishes his public image to win the trust of the people. This is what Foucault terms, as Mills (2003) reports, "the hidden transcripts as well as the public performance" (p. 42). "With the public performance", the Sultan prepares his people for his orders to move to Daulatabad and invites the people to a gathering to point out his mistakes in a public place. He might be the first Sultan to admit his guilt of the illegal appropriation of Vishnu's land, a cloak to hide his vice and tyranny. Moreover, he appoints Vishnu in civil service. People cannot accept this kind of incredulous idealism. It is beyond the practice of Sultans, though it was common during early Islam. By "spreading" justice among his people, he wants to be remembered as one of the Khalifs. Below is his speech which does not correspond to his inhuman actions.

My beloved people, you have heard the judgment of the Kazi and seen for yourselves how justice works in my kingdom - without any consideration of might or weakness, religion or creed. May this moment burn bright and light up our path towards greater justice, equality, progress and peace-not just peace but a more purposeful life. (Karnad, p. 150)

In this "moving" public speech, he introduces his plan to move the capital from Delhi to Daulatabad. The people are not happy with this news and they consider it an act of sheer tyranny. This arrogant Sultan keeps on requesting the people to cooperate with him for his "noble" cause, as he claims it to be. According to him, the new chosen capital will develop strength and bond between the Hindus and the Muslims. He does not consider his speech a "mad whim of a tyrant" (Karnad, p. 150), as he calls it, but "an invitation and not an order" (Karnad, p. 150). Apparently these nice words of this warrior in the path of Allah become gall and yet more gall to come when the citizens of Delhi start to move towards the chosen capital. Agony will be visible. Elderly people and children will find it difficult to move and die in their way end. When the people are reluctant to leave their hometown where they have grown up, the Sultan gets unhappy and shows them his real face, which he hides behind his soft words as in the speech above. Those are the words of the "liberal" Sultan, who pretends to be "human". Nothing will satisfy him except to see Delhi turning into a graveyard: "Not a light should be seen in the windows of Delhi. Not a wisp of smoke should rise from its chimneys. Nothing but an empty graveyard of Delhi will satisfy me now" (Karnad, pp. 186-187).

Ali Ahmed Bakathir's Sir Al-Hakim bi-Amr Allah (1947) also narrates a story of a tyrant who made himself another Pharaoh. The mad Fatimi ruler of Egypt, as described by his people, Al-Hakim bi Amr Al-Lāh proclaimed himself God with the help of his close associates. The play presents how people are forced to be silent and accept what is dictated to them through the agents of the ruler and through wicked means. The ruler attempts to control people and direct them as he likes. He spreads fear among his people and uses excessive power against anyone who opposes him. In this regard, it is necessary to shed light on the four dimensions a ruler relies on to remain in power for a longer time. They are the people's need, care, power and fear. Dr. Alalam (2006) points out these four dimensions and show how the ruler and the ruled are related, which is true of Tuqhlaq and Al-Hakim:

Generally, we can distinguish between four dimensions which control this kind of relationship [between the ruler and his subjects]. The first one is need, which involves dependence and the seeker's need for what wished for, like the need of the body for the soul, the earth for the water and the patient for the doctor. The second one is 
care which involves leniency, beneficence and guidance, like the shepherd with his herd, the father with his son and the guardian with his orphan. The third one is power which imposes others to fear and get crushed before a person who is like the sea with much water but very deep, like the sun and fire which may give warm but they may burn, ... The fourth one is fear which involves cautiousness and keeping distance. Fear does not only result out of assault and power, but results out of the difficulty to predict the Sultan's behaviour, for he resembles a child whose actions are unpredictable. (p. 187)

Al-Hakim has established his relation with his subjects on the basis of those four dimensions. The people's need for the Sultan, the first dimension, has made them submissive, carrying out all his orders. He controls all the resources of the Kingdom and distributes them to his close associates to make the circle around him durable. He attempts to weaken his subjects through need and poverty and creates disputes and conflict among them. For example, when a group of people approaches him for assistance, he agrees on the condition that they first join a fighting contest and the winner will get the gold pieces. He imposes many things on his people so that they always remain in need for his assistance. Care, the second dimension, does not exist during the reign of those two rulers. It increased the gap between the rulers and their subjects. If it existed, the other three dimensions of need, fear and power would have disappeared. Power, of course, is important on the part of the ruler to establish security and balance in the society, but absolute power is the one which people do not like because it corrupts absolutely. During the reign of Tuqhlaq and Al-Hakim, care does not exist. If it appears to exist, it is to achieve a whim of a ruler and it goes against the desires of the subjects.

The other two dimensions of power and fear exist strongly in the play, which make the ruler believe that his people will remain meek and under control as long as he defends the above dimensions. They are manifested through many incidents in the course of the play. During his reign, Al-Hakim punishes wrong doers without bothering about Allah's orders. He establishes his rules and imposes them on his people. He brutally murders innocent people to satisfy his whims and sends his secret agents to spy on.

\section{Misinterpretation and Abuse of Religion}

Misinterpretation and appropriation of Islam is a crucial issue that come under the dictatorship of the Sultan and Al-Hakim. Religion is known as the opium of nations and plays an important role in the stability of a country and in the life of people. It is used by states, rulers or religious scholars to gain certain advantages. Religion cannot be separated from politics and vice versa. In this play, religion is appropriated and used by the Sultan to crush his opponents and it is used by the opposing party to take revenge on the Sultan for his injustice, dictatorship and for his abuse of religion and abuse of power. The third scene of the play presents the conflict between Tughlaq and Sheikh Imam-ud-din for religious and political reasons.

Girish Karnad reflects on this crucial subject of religion. This outsider view about the status quo of a Muslim ruler and his subjects has a relevance to our times in which many nations have revolted against their rulers in many Arab countries. Karnad must have seen or read about the dictatorship of some rulers, and therefore, has gone to the past to point out to his audience the practice of the unjust Sultan. He points out that there is no difference between the present rulers of his times and those of the ancient ones. In the third scene, Karnad reveals the conflict between politics and religion represented respectively by the Sultan and the Sheikh. The dialogue between them on this issue reveals a lot about the Sultan's politics against Islam and eminent Muslim scholars. As an attempt to soothe the Sheikh, who is willing to go to the marketplace and speak to people to defend Islam, the Sultan admits that he is "never consciously against the tenets of Islam" (Karnad, p. 165). The Sheikh expresses his unhappiness with the Sultan because he does not consult the Ulema for the solutions of problematic issues and he tries to convince the Sultan to undertake a real mission to protect Islam and spread it like the Arabs who had a great rule in the early days of Islam.

The hypocrisy of the Sultan and his coterie who attempted their best to polish the public image of their Sultan before his subjects helped him to win the hearts of many people. He managed to turn many of them against his threatening enemies, especially the religious scholars who pose a real threat to his throne. Being tyrant all the time would not work in many situations, therefore, he had to pretend to be democratic and liberal in many situations. The welcoming words of the announcer show the hypocrisy of the Sultan and his false public image. He shows welcome, gentleness and openheartedness to the people but in reality he is opposite. The words of the announcer remind one of the important speeches made by Lady Macbeth to Macbeth so that he can accomplish his mission and achieve his desire- - "To beguile the time, Look like the time. Bear welcome in your eye, Your hand, your tongue. Look like the innocent flower, But be the serpent under't' (Bloom, pp. 102-103). The Sultan wants to beguile the time and his people by welcoming the Sheikh as mentioned in the speech above but he is a serpent under it. The Sultan deceives the people by hiding his feelings and shows the welcoming and gentle 
expression on his face to welcome his guest. He welcomes his guest by forcing people to stay inside their homes and not to turn up to the Big Mosque where the Sheikh is supposed to preach. The Sultan is intelligent and aware of the courage and integrity of Sheikh Imam-ud-din. The announcer publically informs the people to attend the gathering in the Big Mosque to listen to the Sheikh. On the contrary, the soldiers go secretly from door to door ordering people not to attend the gathering or they will be punished. The Sultan adopts the above strategy to retain his power. He is sure that people will revolt against him if they listen to the words of the Sheikh as it has happened in Kanpur.

The possible change led by the active people is a threat to many tyrants and unjust systems. The Sultan as one of those dictators has done his best to block this change. He has kept his people away from the source and has succeeded to keep them like "dumb cattle", otherwise they will threaten his throne. The Sultan could have planned the killing of the Sheikh easily but he knows that this action would trigger violence and riots all over the country. People love Sheikh Imam-ud-din and that is way the Sultan has thought of a better plan to deceive people. The Sultan's wicked plan is to get rid of the Sheikh by sending him to propose peace to Ain-ul-Mulk, who is marching to Delhi to wage a war against the Sultan. As a plan of the Sultan to put the Sheikh and his opponents in a trap, he asks the Sheikh to put on royal dress, Ratansingh describes how the Sheikh looks: "The Sheikh is delighted about being the Sultan's peace emissary. He looks gorgeous-all dressed up in royal robes, a royal turban, even royal slippers, and sitting on the royal elephant. In fact, he looks exactly like the Sultan" (Karnad, p. 173). This striking resemblance between the Sultan and the Sheikh proves the Sultan's intention to get the Sheikh killed by the army of Ain-ul-Mulk and to use the Sheikh as a trap for his opponents as Ratansingh points out in his dialogue with Sheikh Shihab-ud-din (Karnad, p. 24). Thus any attempt that might lead to a change or revolt is encountered and aborted by the Sultan in its early stage.

Sheikh Imam-u-din, like the old man in Wole Soyinka's Madmen and Specialists, attempts to turn people against the present administration and has achieved a positive change. But his fault is that he has not understood the Sultan's motives. The Sheikh believed the Sultan to be his emissary, which resulted in the murder of the Sheikh. Unlike Sheikh Imam-u-din in Tughlaq, the old man in Soyinka's Madmen is experienced and understood Dr Bero's nature and has managed to achieve the desired change by motivating the mendicants. The death of the old man has triggered violence by burning the store signalling the beginning of the revolution against the corrupt system led by Dr Bero, the son of the old man. This revolt indicates that the old man has succeeded in his mission to bring about a positive change in the mind of his supporters so that they can stand against the injustice and tyranny of the system. The end of Sheikh Imam-u-din does not lead to a positive change because of the Sultan's wicked plans to isolate him from his supporters. The Sultan's arrangements for the Sheikh's visit to preach people in Delhi and announce publically that all people have to attend the meeting will make the people suspicious of the Sheikh. The Sheikh has not learned from the first lesson and is tricked again to be the Sultan's envoy to Ain-ul-Mulk. He did not know that the Sultan has plotted his murder to ensure that there shall be no one to threaten his power.

It is not strange that a tyrant, like Tuqhlaq, is branded as a mad ruler for his attitudes, his misinterpretation of religion and his baseless philosophies. Al-Hakim, in Bakathir's play holds the same attitude towards religion. Resembling Tuqhlaq's words to Sheikh Imam-u-din in the third scene, Al-Hakim's speech below manifests his false perception of religion:

Al-Hakim: Oh Allah! These people don't understand the wisdom behind my rules. How can they understand the wisdom behind Your rules? Lord! They are all angry with me. If You are happy with me, I don't care (with them). (His eyes full with tears). My lord, I don't see You are angry with me because I have violated some rules of Your Book, for I want to reform what I can. You have forbidden adultery and I exterminated it by compelling women to stay at home. You have forbidden wine and I eradicated it by uprooting the grape-vines. You have forbidden theft and robbing and I put an end to it by prohibiting people from going out at night. (Bakathir, p. 30)

Al-Hakim distorts the image of Islam and destroys his society by taking up extreme steps. Firstly, he forces woman to stay at home to fight adultery. Secondly, he eradicates grapevine to stop wine production. Thirdly, he prohibits people from going out at night to stop theft. These odd steps contradict the teachings of Islam as laid down in the Holy Quraan and Sunnah. His weird philosophy in establishing security and Allah's commands is also clear through the following dialogue with his sister:

Al-Hakim: I kill those leaders because I love them and that their deeds won't be thwarted if they live afterwards. ... (Bakathir, p. 24)

Settul-Mulk: I can't understand what you say. The policy you are following angered and provoked people and made them wish the downfall of our throne. 
Al-Hakim: (Laughing). You have no idea about the natures of people. They only surrender to the one whom they fear and that their fear is the source of security and harmony in our country ... (Bakathir, p. 25)

Al-Hakim and Tuqhlaq force their people to submit and surrender to them. These two rulers feel that they know what is right for their people and they think that they can do better without the instructions of the Quraan. Tuqhlaq's remarks that he has found another world away from the "Koran" is also true of Al-Hakim who has already found his path. He refers to this in the beginning of the play as mentioned above in his address to Allah.

\section{Crisis of Human Values}

Crises of human values and degradation are miserable aspects during the journey which is imposed on the people. No one before has committed such an act of foolishness by asking people to leave the capital to the new one chosen for them. Shifting to the capital from Delhi to Daulatabad has witnessed several incidents of dehumanisation and devastation. The officers attached to the Sultan exploit people and force them to pay and obey or they will be deprived of the services which have been arranged to meet their needs during the journey. Scene seven, in Tuqhlaq, takes us to an agonizing view, a Hindu woman on a camp screaming: "my child ... please have mercy on it" (Karnad, p. 189). She fails to take him to a doctor because she does not have money to bribe the person in charge, Aziz. The ruthlessness of those officers has resulted in the death of the child. Their excuse is that the child is a hopeless case. In addition, a man states that two corpses were on the road and that they must have walked till their hearts gave out (Karnad, p. 190). Aziz got angry with the man who buried the corpses, because they might belong to a Hindu family and orders him to leave the corpses alone in the future (Karnad, p. 190), an implication to more suffering to come. In addition to those human conditions, an old man was the only one who survived and his family died on their way to the new capital. His words silenced the young man: "My old father had lived in Delhi all his life. He died of a broken heart. Then my son Ismail. He was six years old - would have been ten now! The fine dust that hung in the air, fine as silk, it covered him like a silken shroud. After him, his mother" (Karnad, p. 194). Karnad has presented vivid pictures of the calamities of the helpless people, a man says: "the roads are lined with skeletons. A man starved to death right in front of his eyes. In Doab, people are eating barks off the trees, he says. Yes, and women have to make do with skins of dead horses" (Karnad, p. 209). These appalling conditions of the people are unspeakable and in this regard one remembers Salman Rushdi's Train to Pakistan in which people suffered and lost their dear ones in their journey. However, the journey that Tuqhlaq imposes on his people is not justified and it is due to decision of the Sultan for which his people paid dearly.

The sins of the past, the killings of the innocent people and imbalance have been like chains on the Sultan who has thought for a while of leaving the throne for a peaceful place like Makkah so that Allah may wash away all his sins. Murdering such innocent and pious Sheikhs has certainly shaken him. His disease has become incurable like Lady Macbeth's. It is true that unnatural deeds bring about unnatural diseases and it is the divine interference that can only bring the Sultan peace. The words of Sheikh Imam-ud-din are important in this regard for he has warned the Sultan that playing with politics and religion will rip him into two (Karnad, p. 166). This is the result of "the flash of the Sultan's dagger". In an attempt to reform him, his caring stepmother tries to stop his "unending line of corpses" (Karnad, p. 203) and warns him that his kingdom has become a kitchen of death (Karnad, p. 205) and that the Ulema and the noblemen are against him (Karnad, p. 205). He pays no heed and tells her that murders gave him power and strength (Karnad, p. 204). Instead of his feelings that he has gone wrong, he gives his orders to stone his stepmother to death.

The Sultan, like Dr. Bero, has attempted to get rid of his human weakness to go a step beyond his world. The Sultan and Dr. Bero are similar in their lust for power, for they find themselves belonging to another world. The Sultan finds himself in "a world that he has not found in the Arabs or the Koran" (Karnad, p. 24). Dr. Bero feels that "power comes from bending nature to your will" (Soyinka, p. 237). The Sultan's lust for power is also the same. He is becoming another God and he wants to propose what he thinks is right for his "servants". He calls his people "dumb cattle" and he shall try to "make men out of a few of them" (Karnad, p. 166). He does not recognise them as human beings and he deals with them as animals. His ambition for power has led him to transgression. He thinks that there is no need "to call on God to clean the dirt deposited by men" (Karnad, p. 165). Like Dr Bero who killed his father to get rid of the last human tie to enjoy power, the Sultan too killed his father and brother and committed many crimes afterwards, ending with his stepmother. He declares that these murders give him power and he adds that it is the sword and not the words that bend people to his will.

Al-Hakim goes a step beyond to get rid of his human weakness by killing an innocent child to satisfy his whim. He goes on "contemplating" on the organs of the child's body and describes how Allah has created them. He holds the heart, the liver, the lungs ... etc and asks: "where is that vibrant life? Where is that beauty? All have 
gone. ... Here I have got rid of Mercy. I have got rid of the human weakness" (Bakathir, p. 18). This lust for blood goes on. Another example of his crime is that he cuts off the tongue of a man who has been heard speaking to his wife at bedtime about the ruler. One of the spies reported to the king that one man had been praying to Allah to save this country from this tyrant. The man is shocked to hear this news because no one else was there except his wife. With such kind of practice, he forces people to keep silence and dare not speak a single word against him.

Like Tuqhlaq, Al-Hakim's contradictory personality is clear in his actions, judgments and in his words. He sometimes praises knowledge and scholars and builds schools for them, and he sometimes destroys the schools over their heads. He wears woollen clothes and sits in darkness for many years to practice his favourite sport which he believes will help him get rid of the human weakness to be godlike. He abolishes Zakat, prevents Duha prayer, Taraweeh and Pilgrimage, and orders people to close shops at daytime and opens them at night. His contradictions have extended to the People of the Book as well. He orders the demolition of the Resurrection Church in Jerusalem and forces the Jews and Christians to embrace Islam or leave the country. Al-Hakim's contradictory orders are meant to test the people's loyalty and willingness to obey him. When he notices their submission and obedience, he asks them to worship him. For this purpose, he establishes a centre called the "House of Wisdom" for preparing and guiding Ismailia advocates. Then, he orders people to stand and kneel down when the Imam mentions his name during the sermons as a kind of glorification for him. There are many events in the play which prove Al-Hakim's contradictory nature. He worships Allah seeking his guidance, but he does horrible deeds that a normal man cannot approve of. The story of his maids who beg him to spare their lives shows how inhuman and foolish Al-Hakim is. The reason behind his decision to get rid of them is to stop them from marrying other men and that they are considered to be a temptation. He speaks to Allah that he has got rid of this temptation (Bakathir, p. 49), which he thinks to be a victory over human desires and a step to reach his goal. Like Tuqhlaq in a public place, Al-Hakim attempts to settle issues and claims to do justice to his people. But Al-Hakim proves to be more weird and more eccentric than Tuqhlaq in many aspects. Al-Hakim orders women to stay at home and gives them consents on specific days if they want to go out. One of his people, namely Saeed, uses this order to his advantage and does not give the consent letter to his sister at a suitable time to deprive her of a chance to see her mother in her death bed. Therefore, Saeed has taken all the possessions and the money of his mother depriving his sister of her rights. Al-Hakim confiscates all Saeed's money. When Saeed begs Al-Hakim to have mercy on him, he orders to kill him and to give one third of the property to his sister and two thirds to his wife and children.

Another example of Al-Hakim's weird judgment and dehumanisation is when ten needy people approach him for his assistance he asks them to be divided into two groups and fight each other and the winner will win the five gold coins. They kill each other in the fighting contest except one who is supposed to get the gold. Al-Hakim does not approve of it and does not fulfil his promise. He orders his men to kill the winner because he has killed his brothers for the sake of gold. The men hit the winner with the gold pieces till he dies. His body is taken to his family.

\section{Conclusion}

Thomas Smith's argues, as pointed out by Mary Nyquist, that "Absolute power, is dangerous to those ruled and to the ruler, who is likely to become insolently swollen with pride" (Nyquist, p. 85). Tuqhlaq and Al-Hakim became swollen with pride and did not realize that power alone is not an active mean to keep the kingdom or the country stable. A ruler has to win the hearts of his subjects by doing justice, and by extending good manners, care and love. But in the above plays, the two rulers lack justice, respect and care for their subjects. It is also important that the ruler should not care for the inner thoughts of his subjects and what they think about him. That will not lead to any positive stability in the nation. The moment the two rulers began to suspect their subjects, imbalance and violence begin to emerge. With thoughts of doubts in mind, both Al-Hakim and Tuqhlaq begin to crush their subjects the moment they sense danger approaching them. That Al-Hakim cuts off the tongue of one of the people who is heard at night talking ill of him testifies this. He does this by sending spies at night to listen to what people say about him. Therefore, the power of the ruler should be balanced and accompanied by justice and care and to be based on good terms with his subjects if he wants them to be active participants in establishing security and stability. It is true that those two rulers had lusted for power "to satisfie [their] vicious and cruell appetite, without respect of God, of right or of the law" (Smith, chap 8).

These rulers do not differ much from each other in the way they rule their countries. They both misrepresented Islam and its teachings to suit their whims. They were tyrants and unjust towards their families and their people as well. They killed innocent people, imprisoned, and exiled Sheikhs. They abused religion and used it to their advantage to crush their opponents to stay in power as long as possible. It is noticed that the Sheikhs in Tuqhlaq 
attempted to move the public against the Sultan. When one looks at the religious scholars during the reign of the Sultan, they were united against the Sultan's wrong practices. They showed no personal interests and their cause was to stand against the wrong policies of the Sultan. That's why they risked and sacrificed their lives to serve their nation and religion. They feared Allah and not the Sultan and they had been courageous to say the truth in the face of the unjust Sultan. The religious scholars in Al-Hakim are different for they attempted to polish the image of Al-Hakim in order to mislead him to achieve their grand scheme. They attempted to make god of him so that he would fall in the eyes of the public. With his fall, they hoped to establish their state and to call people for their new religion.

\section{References}

Alalam, E. A. (2006). Al-A'adaab Asultania. Kuwait: International Press.

Bakathir, A. A. (1989). Sir Al-Hakim bi-Amr Allah. Cairo: Egypt Bookshop.

Bloom, H. (Ed.). (2005). Macbeth. New York: Chelsea Housing Publishers.

Glad, B. (2002, March). Why Tyrants Go Too Far: Malignant Narcissism and Absolute Power. Political Psychology, 33. Retrieved September 15, 2013, from JSTOR database.

Karnad, G. R. (1972). Tughlaq. New Delhi: Oxford University Press.

Manser, M. H. (2007). The Facts on File Dictionary of Proverbs. New York: Infobase Publishing.

Mills, S. (2003). Michel Foucault. London: Rutledge. http://dx.doi.org/10.4324/9780203380437

Nyquist, M. (2013). Arbitrary Rule: Slavery, Tyranny, and the Power of Life and Death. Chicago: University of Chicago Press. http://dx.doi.org/10.7208/chicago/9780226015675.001.0001

Rabinow, P. (Ed.). (1984). The Foucault Reader. Pantheon Book, New York.

Smith, T. (1583). De Republica Anglorum. Retrieved September 15, 2013, from http://www.constitution.org/eng/repang.htm

Soyinka, W. (1974). Collected Plays. Oxford: Oxford University Press.

Tandon, N. (Ed.). (2006). Perspectives and challenges in Indian-English drama. New Delhi: Atlantic.

\section{Copyrights}

Copyright for this article is retained by the author(s), with first publication rights granted to the journal.

This is an open-access article distributed under the terms and conditions of the Creative Commons Attribution license (http://creativecommons.org/licenses/by/3.0/). 